\title{
Qualitative and Quantitative Determination of Tryptanthrin, Indirubin, Indican and Isatin Indole Alkaloids During Vegetative and Flowering Stages in the Roots and Leaves of Isatis constricta P. H. Davis
}

\author{
${ }^{*}$ Nesim YILDIZ1®, Özgür KARAKAȘ \\ ${ }^{1}$ Ankara University, Faculty of Agriculture, Department of Field Crops, 06110, Dıșkapı, \\ Ankara, Turkey \\ ${ }^{2}$ Șırnak University, Faculty of Agriculture, Department of Agricultural Biotechnology, \\ Șırnak, Turkey \\ *Corresponding author e-mail (Sorumlu yazar e-posta): nesimyildiz1988@gmail.com
}

Received (Geliș Tarihi): 17.09.2019＜wide>Accepted (Kabul Tarihi): 11.12.2019

\begin{abstract}
Isatis genus more known as the indigo plant is a plant belonging to the Brassicaceae family in Turkey. Turkey has 31 types and 15 subtypes in various provinces. 18 of these species and 3 of the subspecies are assumed as endemic. All taxa of the genus are extensively used in dyeing and treatment of various infections. They contain large number of secondary compounds like phenolics, flavonoids and alkaloids in root, leaf, flower and fruit parts. Among these indole alkaloids like triptanthrin, indirubin, indican and isatin are used in treatment of many diseases. These are obtained from the leaves and roots are pharmacologically active compounds. This study revealed that this biannual herbaceous plant grows $30-50 \mathrm{~cm}$ in length on volcanic slopes, at 1200 - 1300 meters above sea level. It generally grows in Eastern Anatolia and the Mediterranean region of Turkey. The study aimed to determine optimum ontogenetic stage of Isatis constricta to extract natural bio compounds like indirubin, isatin, indican, tryptanthrin. The leaf and root samples used in this study were collected from Maden county of Elazığ province. They were tested for the presence of these compounds during vegetative and flowering period of the plant. The HPLC (HighPerformance Liquid Chromatography) analysis results showed that tryptanthrin $0.482( \pm 0.0072) \mu \mathrm{g} / \mathrm{g}$ and indirubin $0.029( \pm 0.00007) \mu \mathrm{g} / \mathrm{g}$ has the highest concentrations in the leaf samples obtained during the vegetative period. However, isatin $4.358( \pm 0.0985) \mu \mathrm{g} / \mathrm{g}$ and indican $21.330( \pm 0.114) \mu \mathrm{g} / \mathrm{g}$ were found to have the highest concentration in leaf samples obtained during flowering period. When both results are compared, it can be seen that the amount of tryptanthrin, isatin, indirubin and indican alkaloids were found in the leaves of $I$. constricta-higher than to the roots. This research idicate that the most appropriate development stage of $I$. constricta to obtain triptanthrin indirubin, indican and isatin compounds.
\end{abstract}

Keywords: Tryptanthrin, indirubin, indican, isatin, indole alkaloids

Isatis Constricta P. H. Davis'in Köklerinde ve Yapraklarında Vejetatif ve Çiçeklenme Dönemlerinde Triptanthrin İndirubin, İndican ve İsatin İndol Alkaloidlerinin Kalitatif ve Kantitatif Tayini

Öz

Türkiye'de daha çok çivit otu olarak bilinen İsatis cinsi Brassicaceae familyasına ait bir bitkidir. Türkiye'nin çeșitli yerlerinde bu bitkiye ait 31 tür ve 15 alt türü bulunmaktadır. Bu türlerin 18 tanesi ve alttürlerin 3 tanesi endemiktir. Cinsin bütün taksonları çeşitli enfeksiyonların tedavisinde ve boyamada yaygın olarak kullanılmaktadır. Kök, yaprak, çiçek ve meyve kısımlarında fenolikler, flavonoidler ve alkaloidler gibi çok sayıda ikincil bileșik bulunmaktadır. Bunlar arasında triptanthrin, indirubin, indican ve isatin gibi alkaloidler birçok hastalığın tedavisinde kullanılmaktadır. Bunlar hem yapraklar hem de köklerden elde edilen farmakolojik olarak aktif bileșiklerdir. Bu çalıșmada kullanılan bitkisi $30-50 \mathrm{~cm}$ kadar boylanan, deniz seviyesinden 1200 - 1300 metre yüksekte volkanik yamaçlarda bulunan iki yıllık önemli otsu bir bitkidir. Bu bitki genellikle Doğu Anadolu ve Türkiye'nin Akdeniz bölgesinde doğal olarak yetișmektedir. Bu çalıșmanın 
amacı, Isatis constricta 'da bulunan indirubin, isatin, indican, triptanthrin gibi doğal bileșikleri elde etmek için bitkinin en uygun gelișim dönemini belirlemek ve bu bileșiklerin bitkinin hangi kısımlarında daha fazla miktarda bulunduklarını tespit etmektir. Bu çalıșmada kullanılan yaprak ve kök örnekleri Elazığ ili Maden ilçesinden toplanmıștır. Test edilen bu örnekler bitkinin vejetatif ve çiçeklenme dönemlerinde toplanılmıștır. HPLC (Yüksek Performanslı Sıvı Kromatografisi) analiz sonuçlarıyla, triptanthrin $0.482( \pm 0.0072) \mu g / g$ ve indirubinin $0.029( \pm 0.00007) \mu \mathrm{g} / \mathrm{g}$ bileșikleri vejetatif döneminde elde edilen yaprak örneklerinde en yüksek konsantrasyonlara sahip olduğu tespit edilmiştir. Ancak isatin $4.358( \pm 0.0985) \mu \mathrm{g} / \mathrm{g}$ ve indican 21.330 $( \pm 0.114) \mu \mathrm{g} / \mathrm{g}$ çiçeklenme döneminde elde edilen yaprak örneklerinde en yüksek konsantrasyona sahip oldukları tespit edilmiștir. Her iki sonuca da bakıldığında I. constricta'nın yapraklarında bulunan triptantrin, Isatin, indirubin ve indican alkaloidlerinin miktarı, köklerine oranla daha yüksek olduğu görülmektedir Bu çalıșma sonucunda triptanthrin, indirubin, indican ve isatini elde etmek için I. constricta'nın en uygun gelișim dönemi ile bitki kısımları belirlenmiștir.

Anahtar Kelimeler: Tryptanthrin, indirubin, indican, isatin, indol alkaloidler

\section{Introduction}

The genus Isatis, family Brassicaceae with 31 species and 15 subspeciesis popularly known as indigo herb has 18 species and 3 subspecies that are highly endemic (Mısırdalı, 1985, Güner et al., 2012).

I. constricta (Figure 1) is a biannual herbaceous plant with short life span. The length of the stem is $30-50 \mathrm{~cm}$ and it is hairless. The leaves on the bottom of the stalk have a long, matte green, hairless, fairly stiff and dull structure. In addition, the lower leaves have a serrated structure with the ends of the leaves usually facing upwards. The leaves on the upper part of the stalk have a long and winged structure. The flowers are $3 \mathrm{~mm}$ in size and the seams are hairless (Figure 2). The size of the fruit is $14 \times 18-3 \times 4 \mathrm{~mm}$ and it has a hard and long structure. The end point of the fruit is cut. The plant is usually found on volcanic slopes, spreading at altitudes of 1200 - 1300

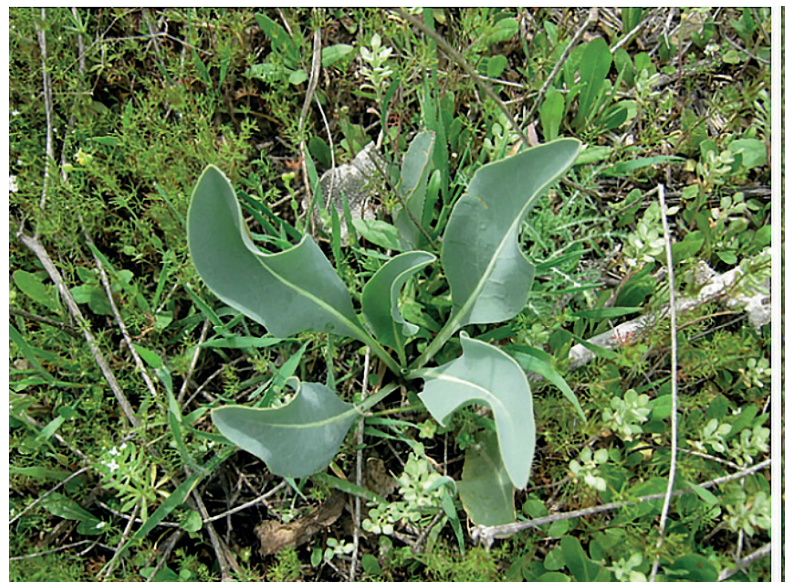

(a)

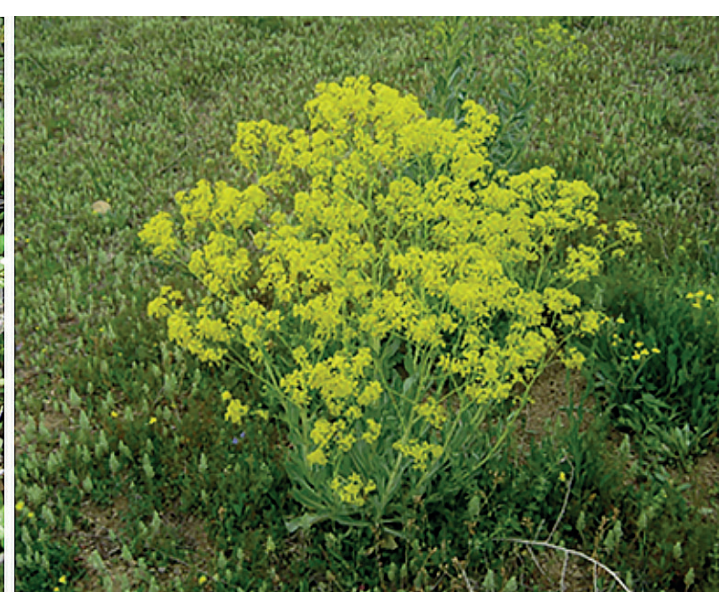

(b)

meters above sea level. I. constricta illustrates widespread distribution in Eastern Anatolia and the Mediterranean region of Turkey (Davis, 1965-1985).

Isatis L. is an important species for both dye and therapeutic use. In China, the root of this plant is called "Ban-Lan-Gen" and its leaves are called "Da-Qing-Ye". The root and leaves of Isatis are source of indigo (blue), one of the earliest dyestuffs used in history (Chang and Ho, 2001). These plants are also used for the treatment of influenza, psoriasis, mumps, pharyngitis and hepatitis (Bown, 1995).

Almost all taxa of the genus /satis are being used in many European countries in dyeing, and treatment of injuries, ulcers, tumors, hemorrhoids, snake bites and in various infections (Hamburger, 2002).

stage and flowering stage

Șekil 1. a. ve b. Isatis constricta'nın vejetatif ve çiçeklenme dönemlerindeki görüntüsü 
A number of studies have been carried out to find the chemical compounds, phenolics, flavonoids and alkaloids of Isatis taxa found in their roots, leaves, flowers and fruits (Oksay and Oksay, 2009). Among these compounds, indole alkaloids like triptanthrin, indirubin, indican and isatin indole compounds are used in the treatment of many diseases (Zou and Koh, 2007).

\section{Compounds in Isatis $L$.}

All species in the genus Isatis contain number of economically important secondary terminal metabolites called alkaloids, phenolic compounds, terpenoids, etc. These have ability to facilitate in pollination improve chemical defence against microorganisms, during various stages of plant growth and development (Vanisree et al. 2004). The amount of these compounds vary depending on cell types, ontogenetic stages of plants and organs of plants (Boege and Marquis, 2005). These compounds are used by human beings in medicine, cosmetics, food industry and pharmaceutical industry (KırıcI, 1998). A large number of alkaloids including indole alkaloids, such as indirubin, Tryptanthrin, isatan, indican etc. have been isolated from the roots and leaves of the Isatis taxa Liau et al. 2007).

Indububin makes a pinkish color compound that is used for dyeing. In addition, it is also important in treatment of myelogenous leukemia, tumor diseases, treatment of wounds and strengthening human immune system (Hoessel et al. 1999; Spink et al. 2003).

Tryptanthrin is obtained from almost all /satis taxa, including Isatis tinctoria and I. indigotica. Tryptanthrin, is a weak basic alkaloid, used as an important compound in pharmaceutical industry to treat human inflammation, some types of tumors. leukemia (Kimoto et al. 2001; $\mathrm{Yu}$ et al. 2009) and strengthening immune system (Takei et al. 2003; Recio et al. 2006) tryptanthrin is also used as an important yellow coloring dyestuff (O’Neill, 1892).

Isatin is an oxidized indole with pharmaceutical uses as antitumor, antimicrobial, anti-inflammatory, analgesic, anticonvulsant (anticoagulant), antiviral, antioxidant, and control of CNS depressant activities like numerous biological disorders (Medvedev et al. 2007). Isatin is also one of the precursors of the red color. It forms a blue colored dyewhen mixed with sulfuric acid and pure benzene, (Da Silva et al. 2001).

Indican is used as a precursor in the synthesis of blue colored natural dye indigo. (Da Silva et al. 2001).

In brief these compounds form an important class of alkaloids, are among the basic and active secondary compounds of Isatis genus members (Ensley et al. 1983; Alex et al. 2010).

In view of the above description, the aim of this study was to determine the optimal ontogenetic stage of these plants during growth to extract these four compounds.

\section{Materials and Methods}

HPLC analysis of indirubin, tryptanthrin, indacan and isatin compounds

\section{Chemical substances used}

Indirubin ( $\geq 98 \%$ ), isatin ( $\geq 99 \%$ ), tryptanthrin ( $\geq 99 \%$ ) indican (indoksil $\beta$-d-glukozid, $\geq 97 \%$ ), acetonitrile ( $\geq 99.9 \%)$, methanol $(\geq 99.9 \%)$, $\mathrm{N}, \quad \mathrm{N}$-dimethylformamide (DMF) ( $\geq 99.9 \%)$ and trifluoroacetic acid (TFA ) ( $\geq 99.9 \%)$ was obtained from the Merck company (Germany).

\section{Plant collection}

The samples of $l$. constricta used as material in the study were collected from the mountainous area of Elazığ-Maden district (about $1200 \mathrm{~m}$ above sea level) in July 2015. The samples taken from leaves and roots the plants in both vegetative and flowering period were dried under cool and shady place and then stored in refrigerator $\left(+4^{\circ} \mathrm{C}\right)$ until extraction (analysis) and analysis. The plants identified by Prof. Dr. Ömer SAYA (Dicle University, Faculty of Arts and Sciences, Department of Biology, Botany).

The voucher samples of the plants used in the study are kept in the biotechnology laboratory of the Sirnak University, Faculty of Agriculture.

Extraction of indirubin, tryptanthrin, indican and isatin compounds

The dried samples for each ontogenetic 
stage were pulverized in a grinding machine; ensued by taking about $200 \mathrm{mg}$ samples from each plant part, by adding $10 \mathrm{~mL}$ of methanol. It was followed by their extrudation for 10 minutes in an ultrasonicator (Jeiotech, US-05, Korea). After extraction, the resulting solution was vacuum filtered. These operations were repeated 3 times. The methanol fractions obtained at the end of the three treatments were collected in $50 \mathrm{~mL}$ glass flasks. After removal of the methanol by evaporator (Labtech EV311, Evaporator), the residue was formed in the vessel containing indole compounds. This residue was reconstituted to $40 \mathrm{~mL}$ with methanol and passed through 0.45 $\mu \mathrm{m}$ nylon filters before analysis. The methanol extracts, containing both the mobile phase and the compounds, were filtered through a $0.45 \mu \mathrm{m}$ pore size filter prior to analysis and
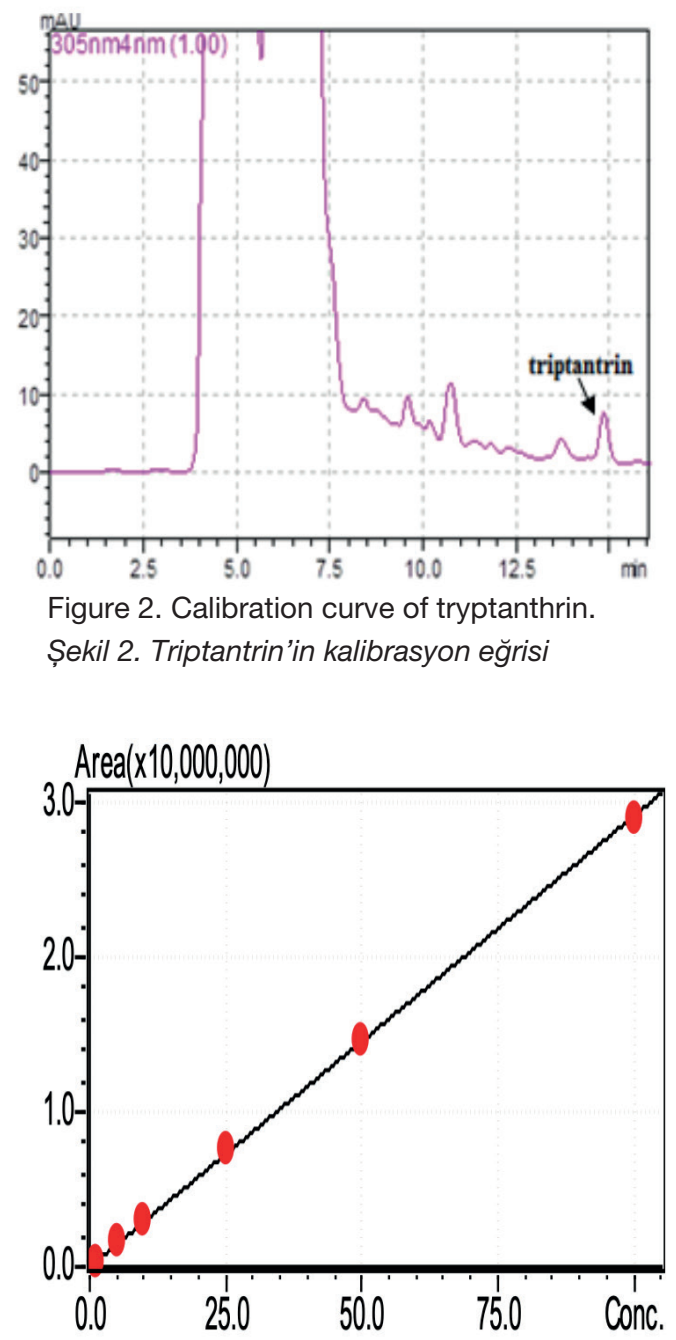

Figure 4. Calibration curve of indirubin Șekil 4. Indirubin'in kalibrasyon eğrisi. subjected to 7 minutes of ultrasonication to remove air bubbles in respective solutions.

Calibration curve for indirubin, tryptanthrin, indican and isatin

Tryptanthrin, indirubin, and indican compounds were dissolved in DMF, and isatin was dissolved in methanol. Stock standard solutions of the each compound were prepared at a concentration of $1 \mathrm{mg} / \mathrm{mL}$. The working solutions were prepared by diluting 1:1 with the appropriate solvent at concentrations of $5,10,25,50,100 \mu \mathrm{g} / \mathrm{mL}$. The times at which the peaks of the typtanthrin, indirubin, isatin and indacan compounds were detected were respectively; 14.9, 13.6, 12.2 and $7.9 \mathrm{~min}$. (Figure 3,5,7,9). Each standard was repeated three times to generate the calibration curve (Figure 2,4,6,8).

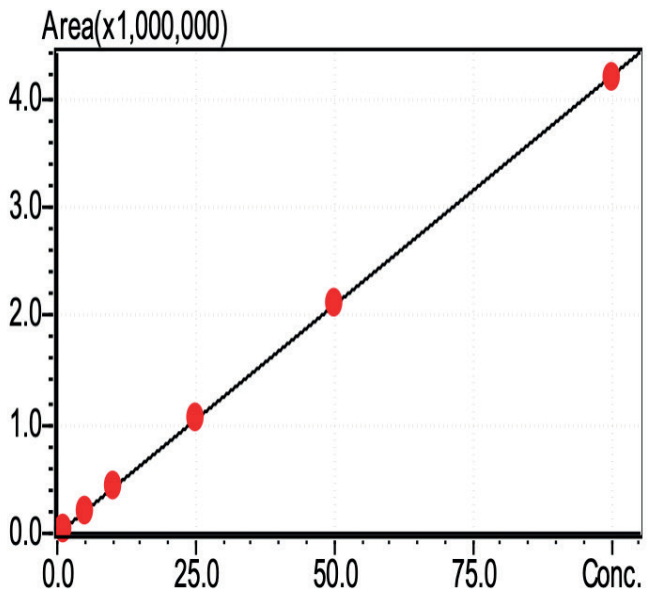

Figure 3. HPLC chromatogram of tryptanthrin. Șekil 3. Triptantrin'in HPLC kromatogramı.

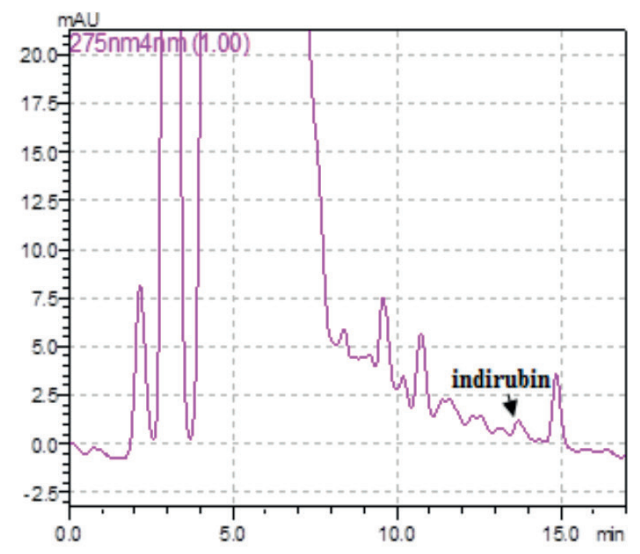

Figure 5. HPLC chromatogram of indirubin Șekil 5. Indirubin'in HPLC kromatogramı. 


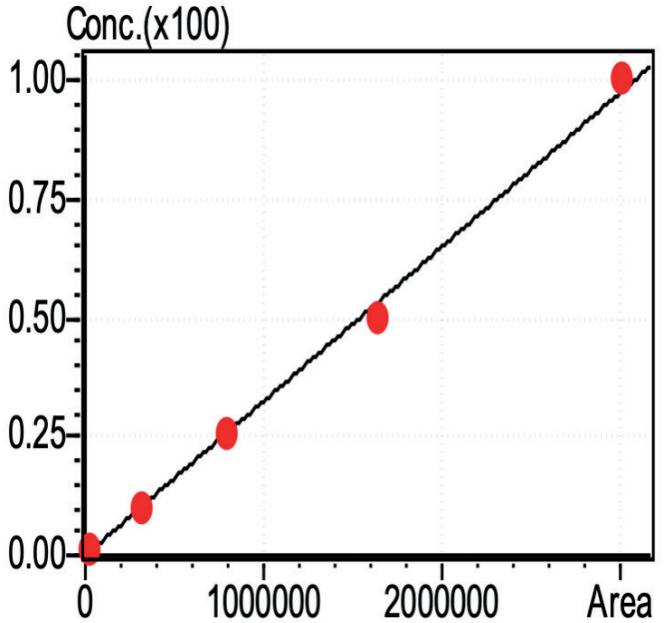

Figure 6. Calibration curve of Isatin.

Șekil 6. İsatin'in kalibrasyon eğrisi.

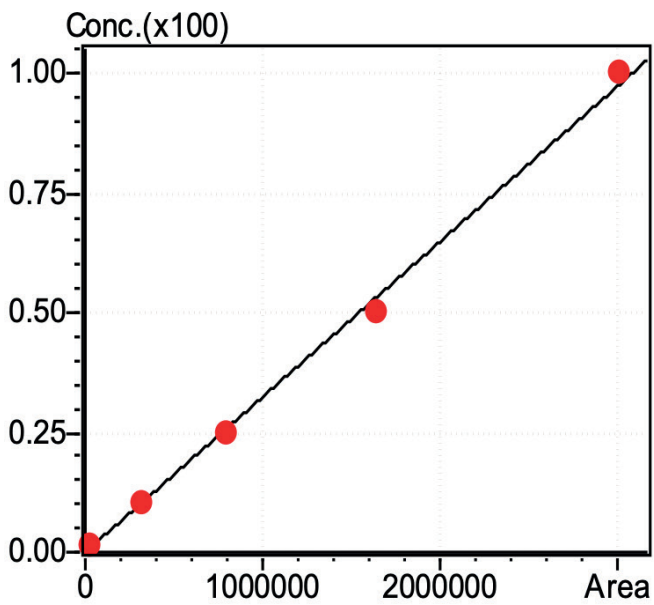

Figure 8. The calibration curve of indican Șekil 8. Indikan'ın kalibrasyon eğrisi.

Analiysis of indirubin, tryptanthrin, indican and isatin

Shimadzu Prominence HPLC was used for the analysis. In the HPLC device, LC-20AT pump, SIL 20A-HT automatic sampler, DGU 20A5R degasser, SPD M-20A detector and Inertsil ODS-4 C18 column $(5 \mu \mathrm{m} \times 4.6 \mathrm{~mm} \times$ $250 \mathrm{~mm}$ ) were used. Analysis conditions for tryptanthrin; the mobile phase was $305 \mathrm{~nm}$ wavelength and isocratic elution profile as $60 / 40$ water/acetonitrile and $0.1 \%$ TFA. The flow rate was $0.5 \mathrm{~mL} / \mathrm{min}$, column temperature was $30^{\circ} \mathrm{C}$ during analysis. The analysis conditions for indirubin were the same as those for tryptanthrin analysis, but the wavelength was $275 \mathrm{~nm}$.

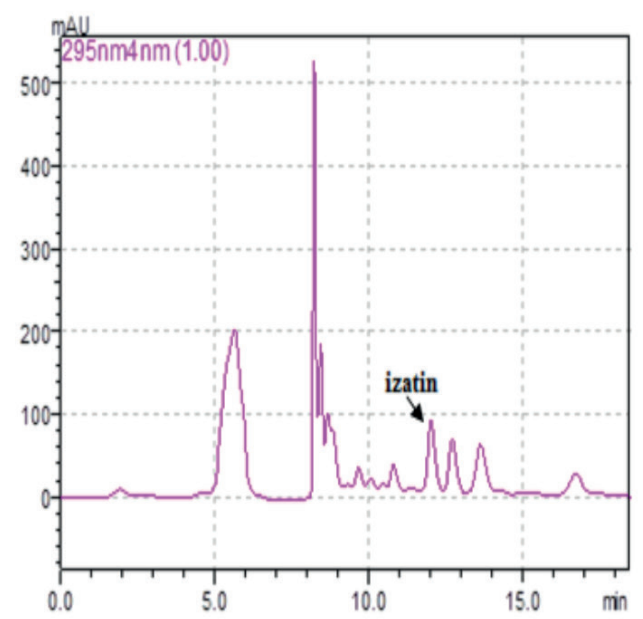

Figure 7. HPLC chromatogram of Isatin. Șekil 7. İsatin'in HPLC kromatogramı.

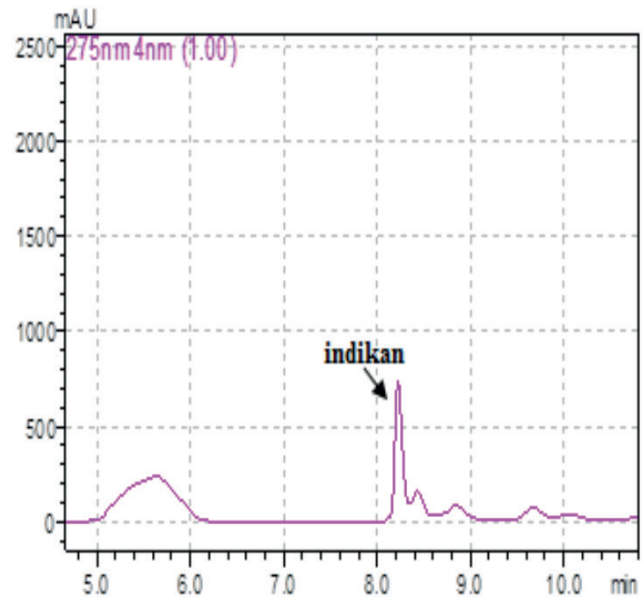

Figure 9. HPLC chromatogram of indican Șekil 9. Indikan'ın HPLC kromatogramı

Analysis conditions for isatin; the mobile phase was a $295 \mathrm{~nm}$ wavelength and isocratic elution profile with a water/acetonitrile ratio of $65 / 35$ and a TFA of $0.1 \%$. The flow rate was $0.5 \mathrm{~mL} / \mathrm{min}$, column temperature was $30^{\circ} \mathrm{C}$.

The analytical conditions for the indican were the same as those for isatin, but the wavelength of $275 \mathrm{~nm}$ was used.

\section{Statistical analysis}

Statistical analyzes were performed with SPSS (version 16.0) Multi-Variate Analysis at $p<0.05$ to significant differences among means along with computation of standard error (S.E.). 


\section{Result and Discussion}

The results obtained from the study are given in Table 1. It was seen that the amount of tryptanthrin, Indirubin, isatin and indican alkaloids found in the leaves of $I$. constricta is higher compared to roots. Whereas, the highest percentage of Indirubin in I. constricta was found during vegetative period (Table 1).

The values on the chart indicate the average of 3 replications. $p$ value less than 0.05 seems to be important in terms of showing differences amng the means of the data according to the multivariate analysis as confirmed by Duncan Multiple Range Test. Both leaves and roots were collected and analyzed during flowering and vegetative periods each.

It was determined that the amount of 0.482 $( \pm 0.0072) \mu \mathrm{g} / \mathrm{g}$ tryptanthrin found in the leaf samples taken during the vegetative period of I. constricta was the highest. The amount of tryptanthrin detected in root samples taken during the vegetative and flowering periods was $0.050( \pm 0.0013) \mu \mathrm{g} / \mathrm{g}$ and $0.063( \pm$ $0.0031) \mu \mathrm{g} / \mathrm{g}$ and showed was statistically non significant differences (Table 1).

Oberthür et al. (2004) found that the percentage of tryptanthrin in the leaf extracts of $I$. tinctoria collected from the wild in June, July and August of 2001 and 2002 was 0.08 $0.17 \mu \mathrm{g} / \mathrm{g}$ in the leaf samples. It was $0.55 \mu \mathrm{g} / \mathrm{g}$ in the leaf samples during July and August 2001. Whereas, the percentage of tryptanthrin was $0.345( \pm 0.0038)-0.482( \pm 0.0072) \mu \mathrm{g} / \mathrm{g}$ as detected during flowering and vegetative periods is close to the maximum value compared to the tryptanthrin percentage obtained in the previous study. In the same study, it was observed that the percentage of tryptanthrin in leaf samples dried at room temperature was $0.6-2.0 \mu \mathrm{g} / \mathrm{g}$, which is higher compared to the results of this study.

Liau et al. (2007) examined 6 dried leaves and 6 dried root samples from 12 samples of $I$. indigotica plants collected from different regions of China, and the amounts of tryptanthrin found in these extracts ranged 34.2 to $109.7 \mu \mathrm{g} / \mathrm{g}$ in leaves and 0.110 to $0.614 \mu \mathrm{g} / \mathrm{g}$ in tryptanthrin contents of root samples. The results of Liau et al (2007). showed significantly higher results compared to the results from root samples in the present studyduring vegetative and flowering periods. Present study showed tryptanthrin amount of $0.050( \pm 0.0013)$ and $0.063( \pm 0.0031)$ $\mu \mathrm{g} / \mathrm{g}$ during vegetative and flowering period respectively from root samples. Similarly, tryptanthrin amount of $0.345( \pm 0.0038)$ and $0.482( \pm 0.0072) \mu \mathrm{g} / \mathrm{g}$ was noted during flowering and vegetative period in the same order from the leaf samples.

The amount of indirubin $0.0105( \pm 0.00029)$ $\mu \mathrm{g} / \mathrm{g}$ in the root samples of $I$. constricta collected during the vegetative period was lower compared to their amount of $0.029( \pm$ $0.00007) \mu \mathrm{g} / \mathrm{g}$ noted during the vegetative period in the leaf samples. There was no significant difference between the results of the study and the indirubin content of the leaf samples in the vegetative and flowering period of $I$. constricta. However, when Table 1 is examined, it was determined that the value of Indirubindetermined as $0.0105( \pm$ $0.00029) \mu \mathrm{g} / \mathrm{g}$ in the root at vegetative stage was higher compared to its value at flowering stage determined as $0.0085( \pm 0.00024) \mu \mathrm{g} / \mathrm{g}$.

Table 1. Indole alkaloid contents of leaf and root parts of I. constricta $(\mu \mathrm{g} / \mathrm{g})$

Çizelge 1. I. Constricta'nın yaprak ve kök kısımlarının Indole alkaloid içerikleri $(\mu \mathrm{g} / \mathrm{g})$

\begin{tabular}{|c|c|c|c|c|c|}
\hline \multicolumn{2}{|c|}{$\begin{array}{l}\text { Ontogenetic stage of } \\
\text { taking samples }\end{array}$} & \multirow[t]{2}{*}{ Tryptanthrin $(\mu \mathrm{g} / \mathrm{g})$} & \multirow[t]{2}{*}{ Indirubin $\mu \mathrm{g} / \mathrm{g}$} & \multirow[t]{2}{*}{ Isatin $\mu \mathrm{g} / \mathrm{g}$} & \multirow[t]{2}{*}{ Indican $\mu \mathrm{g} / \mathrm{g}$} \\
\hline Vegetative & Flowering & & & & \\
\hline \multirow[t]{2}{*}{ leaf } & & $0.482 \pm 0.007 a$ & $0.0290 \pm 0.00007 a$ & $4.243 \pm 0.1683 a$ & $15.348 \pm 0.092 b$ \\
\hline & leaf & $0.345 \pm 0.0038 b$ & $0.0027 \pm 0.00016 d$ & $4.358 \pm 0.0985 a$ & $21.330 \pm 0.114 a$ \\
\hline \multirow[t]{2}{*}{ root } & & $0.050 \pm 0.0013 c$ & $0.0105 \pm 0.00029 b$ & $0.156 \pm 0.0153 b$ & $1.856 \pm 0.015 c$ \\
\hline & root & $0.063 \pm 0.0031 \mathrm{c}$ & $0.0085 \pm 0.00024 \mathrm{c}$ & $0.166 \pm 0.0104 b$ & $1.580 \pm 0.103 c$ \\
\hline
\end{tabular}

a, b ve c : p değerinin 0.05’ten küçük olması veriler arasındaki farklılıkların önemli olduğunu göstermektedir.

$a, b$ and $c: p$ values less than 0.05 indicate that the differences between the data are significant. 
This difference appears to be statistically significant.

Zou and Koh (2007), found amount of $1.01-34.4 \mu \mathrm{g} / \mathrm{g}$ of indirubin in the roots of I. indigotica species collected from different regions of China. Furthermore, Liau et al. (2007) noted mount of $2.384-0.224 \mu \mathrm{g} / \mathrm{g}$ indirubin in dried root extracts of $6 \mathrm{I}$. indigotica plants collected from different regions of China .It was observed that the amount of indirubin present in root and leaf samples collected during the vegetative and flowering periods of $I$. constricta is very low Compared with the above mentioned studies.

This study determined the amount of isatin determined as $4.243( \pm 0.1683)$ and 4.358 $( \pm 0.0985) \mu \mathrm{g} / \mathrm{g}$ in leaf samples taken during vegetative and flowering periods as statistically similar. Similarly, the root samples of the plant contained statistically similar amount of 0.156 $( \pm 0.0153)$ and $0.166( \pm 0.0104) \mu \mathrm{g} / \mathrm{g}$ isatin during vegetative and flowering periods in the same order. However, statistically difference was found in the amount of isatin in leaves and roots at both stages

In their study, Zou and Koh (2007) found that the amount of isatin in the leaves of $I$. indigotica from different regions of China ranged 18.4 to $98.9 \mu \mathrm{g} / \mathrm{g}$. Whereas, Guo and Chen (1986) noted amount of $1.07-1.13 \mu \mathrm{g} / \mathrm{g}$. isatin I. indigotica leaves Compared with these values, the amounts of isatin in the leaf parts during vegetative and flowering period was determined as $4.243( \pm 0.1683)$ and 4.358 $( \pm 0.0985) \mu \mathrm{g} / \mathrm{g}$ that was significantly lower to the amount detected by Zou and Koh (2007). The differences in the result could be due to the use of different species in the two studies.

Zou and Koh (2007) found that the amount of isatin taken from the roots of $I$. indigotica, gathered from different regions of China, ranged 0.30 to $3.45 \mu \mathrm{g} / \mathrm{g}$. This amount was higher than the isatin content of $0.156( \pm$ $0.0153)$ and $0.166( \pm 0.0104) \mu \mathrm{g} / \mathrm{g}$ in the root samples of the plant during the vegetative and flowering periods of $I$. constricta in this study (See Table 1).

Indican amount of $15.348( \pm 0.092)$ and $21.330( \pm 0.114) \mu \mathrm{g} / \mathrm{g}$ was found in leaf samples collected during the flowering and vegetative periods of $I$. constricta was higher than the index amount $1.580( \pm 0.103)-1.856$ $( \pm 0.015) \mu \mathrm{g} / \mathrm{g}$. The difference between the indican values found in leaf samples collected during the vegetative and flowering periods of I. constricta was significantly different, while the difference between the indican quantities found in the root samples was not significantly different (see Table 1).

Zou and Koh (2007) found that the amount of indican residues in the leaves of $I$. indigotica, collected from different regions of China, ranged 12.80 to $29.40 \mu \mathrm{g} / \mathrm{g}$. Compared with these values, the indican amount detected in leaf samples taken from 1 . constricta in flowering $21.330( \pm 0.114) \mu \mathrm{g} / \mathrm{g}$ and vegetative periods $15.348( \pm 0.092) \mu \mathrm{g} / \mathrm{g}$ is almost parallel.

Wenying et al. (2000) found that the amount of indican residues in the leaves of I. indigotica was $305.2 \mu \mathrm{g} / \mathrm{g}$. These values appear to be quite high to $15.348( \pm 0.092)$ and $21.330( \pm$ $0.114) \mu \mathrm{g} / \mathrm{g}$ in leaf samples taken during the flowering and vegetative periods in this study.

The indican amounts $1.580( \pm 0.103)$ and $1.856( \pm 0.015) \mu \mathrm{g} / \mathrm{g}$ found in root samples collected during the flowering and vegetative periods of $I$. constricta in this study (Table 1), was significantly lower compared to their values of $43.6 \mu \mathrm{g} / \mathrm{g}$ values found in the roots of I. indigotica by Zou and Koh (2007).

\section{Conclusion}

Indole alkaloids found in plants belonging to the genus /satis are considered as important compounds both in medical terms and because of their dye properties in wool and textile industry. Among these, tryptanthrin, indirubin, isatin and indican are important compounds found in Isatis species.

If tryptanthrin and indirubin are to be used, it is recommended that the leaf parts of the $I$. constricta plant collected during the vegetative period be evaluated. However, it is recommended that leaf samples collected during flowering period of the plant should be evaluated even if isatin and indican substances are going to be used. 


\section{References}

Alex, D., Lam, I. K., Lin, Z., \& Lee, S. M. Y. (2010). Indirubin shows anti-angiogenic activity in an in vivo zebrafish model and an in vitro HUVEC model. Journal of ethnopharmacology, 131(2), 242-247.

Boege, K., \& Marquis, R. J. (2005). Facing herbivory as you grow up: the ontogeny of resistance in plants. Trends in ecology \& evolution, 20(8), 441-448.

Bown, D. (1995). The Royal Horticultural Society encyclopedia of herbs \& their uses. Dorling Kindersley Limited.

Chang, Y. S., \& Ho, Y. L. (2001). Studies on the Homonymic Chinese Crude Drug Species in Taiwan Evaluation of the Quality of Da-ChingYeh and Ching-Dai. In Analytical Sciences/ Supplements Proceedings of the Sixth Asian Conference on Analytical Sciences (ASIANALYSIS VI) (pp. a423-a426). The Japan Society for Analytical Chemistry.

Da Silva, J. F., Garden, S. J., \& Pinto, A. C. (2001). The chemistry of isatins: a review from 1975 to 1999. Journal of the Brazilian Chemical Society, 12(3), 273-324.

Davis, R. D., Palmer, S. M., \& Lawrence, C. M. (2006). 198: Improving outcomes in lung transplantation. The Journal of Heart and Lung Transplantation, 25(2), S112.

Ensley, B. D., Ratzkin, B. J., Osslund, T. D., Simon, M. J., Wackett, L. P., \& Gibson, D. T. (1983). Expression of naphthalene oxidation genes in Escherichia coli results in the biosynthesis of indigo. Science, 222(4620), 167-169.

Guo, Y., \& Chen, F. (1986). TLC-UVspectrophotometric and TLC-scanning determination of isatin in leaf of Isatis. Zhongcaoyao, 17, 8-11.

Güner, A., \& Aslan, S. (Eds.). (2012). Türkiye bitkileri listesi:(damarlı bitkiler). Nezahat Gökyiğit Botanik Bahçesi Yayınları.

Hamburger, M. (2002). Isatis tinctoria-from the rediscovery of an ancient medicinal plant towards a novel anti-inflammatory phytopharmaceutical. Phytochemistry Reviews, 1(3), 333.

Hoessel, R., Leclerc, S., Endicott, J. A., Nobel, M. E., Lawrie, A., Tunnah, P., \& Niederberger, E. (1999). Indirubin, the active constituent of a Chinese antileukaemia medicine, inhibits cyclindependent kinases. Nature cell biology, 1(1), 60.

Kırıcı, S. (1998). Dyestuffs Obtained from Natural Waters. Ç.Ü.Z.F. Magazine, 9-11.

Kimoto, T., Hino, K., Koya Miyata, S., Yamamoto, Y., Takeuchi, M., Nishizaki, Y., \& Kurimoto, M. (2001). Cell differentiation and apoptosis of monocytic and promyelocytic leukemia cells (U937 and HL60) by tryptanthrin, an active ingredient of Polygonum tinctorium Lour. Pathology international, 51(5), 315-325.

Liau, B. C., Jong, T. T., Lee, M. R., \& Chen, S. S. (2007). LC-APCI-MS method for detection and analysis of tryptanthrin, indigo, and indirubin in Daqingye and Banlangen. Journal of pharmaceutical and Biomedical Analysis, 43(1), 346-351.

Medvedev, A., Buneeva, O., \& Glover, V. (2007). Biological targets for isatin and its analogues: implications for therapy. Biologics: targets \& therapy, 1(2), 151.

Misirdali, H. (1985). Taxonomic and cytological investigations on the species of Isatis L., grown in the Eastern and South Eastern Anatolia and over the regions of Eastern Mediterranean. Project No: TBAG-535, 139.

Oberthür, C., Schneider, B., Graf, H., \& Hamburger, M. (2004). The elusive indigo precursors in woad (Isatis tinctoria L.)-identification of the major indigo precursor, isatan $A$, and a structure revision of isatan B. Chemistry \& biodiversity, 1(1), 174-182.

Oksay, D., Oksay, M. (2009). Bitki Sekonder Metabolitlerinin Biyoteknolojik Önemi e-Journal of New World Sciences Academy Ecological Life Sciences, 4: 31-41.

O’Neill, C. (1892). Products from indigo-blue. Chem. News, 65, 124.

Recio, M. C., Cerdá-Nicolás, M., Potterat, O., Hamburger, M., \& Ríos, J. L. (2006). Antiinflammatory and antiallergic activity in vivo of lipophilic Isatis tinctoria extracts and tryptanthrin. Planta medica, 72(06), 539-546.

Spink, B. C., Hussain, M. M., Katz, B. H., Eisele, L., \& Spink, D. C. (2003). Transient induction of cytochromes P450 1A1 and 1B1 in MCF-7 human breast cancer cells by indirubin. Biochemical pharmacology, 66(12), 2313-2321.

Takei, Y., Kunikata, T., Aga, M., Inoue, S. I., Ushio, S., Iwaki, K., \& Kurimoto, M. (2003). Tryptanthrin inhibits interferon- $\gamma$ production by Peyer's patch lymphocytes derived from mice that had been orally administered staphylococcal enterotoxin. Biological and Pharmaceutical Bulletin, 26(3), 365-367.

Tian, G., \& Ying, R. (2000). TLC Determination of Indican in the Radix Isatidis Folium Isatidis and Granules of Banlangen. Chinese Journal of Pharmaceutical Analysis, 20(5), 322-323.

Vanisree, M., Lee, C. Y., Lo, S. F., Nalawade, S. M., Lin, C. Y., \& Tsay, H. S. (2004). Studies on the production of some important secondary metabolites from medicinal plants by plant tissue cultures. Bot. Bull. Acad. Sin, 45(1), 1-22.

Yu, S. T., Chen, T. M., Chern, J. W., Tseng, S. Y., \& Chen, Y. H. (2009). Downregulation of GST $\pi$ expression by tryptanthrin contributing to sensitization of doxorubicin-resistant MCF7 cells through c-jun $\mathrm{NH} 2$-terminal kinasemediated apoptosis. Anti-Cancer Drugs, 20(5), 382-388.

Zou, P., \& Koh, H. L. (2007). Determination of indican, isatin, indirubin and indigotin in Isatis indigotica by liquid chromatography/electrospray ionization tandem mass spectrometry. Rapid Communications in Mass Spectrometry: An International Journal Devoted to the Rapid Dissemination of Up to the Minute Research in Mass Spectrometry, 21(7), 1239-1246. 